\title{
OPEN Publisher Correction: Role of PKC in the Regulation of the Human Kidney Chloride Channel CIC-Ka
}

Andrea Gerbino, Roberta De Zio, Daniela Russo, Luigi Milella, Serena Milano,
Giuseppe Procino, Michael Pusch, Maria Svelto \& Monica Carmosino

Correction to: Scientific Reports https://doi.org/10.1038/s41598-020-67219-8, published online 24 June 2020

The Funding section in this Article was omitted. The Funding section should read:

"MC was supported by a grant from the Italian Research Ministry (n. ARS01_01081). MP was supported by a grant from the Fondazione AIRC per la Ricerca sul Cancro (grant \# IG 21558) and by a grant from the Italian Research Ministry (PRIN 20174TB8KW)."

(1) Open Access This article is licensed under a Creative Commons Attribution 4.0 International License, which permits use, sharing, adaptation, distribution and reproduction in any medium or format, as long as you give appropriate credit to the original author(s) and the source, provide a link to the Creative Commons licence, and indicate if changes were made. The images or other third party material in this article are included in the article's Creative Commons licence, unless indicated otherwise in a credit line to the material. If material is not included in the article's Creative Commons licence and your intended use is not permitted by statutory regulation or exceeds the permitted use, you will need to obtain permission directly from the copyright holder. To view a copy of this licence, visit http://creativecommons.org/licenses/by/4.0/.

(C) The Author(s) 2020 